\title{
Utility of internally transcribed 16S-23S rDNA spacer regions for the definition of Pseudomonas stutzeri genomovars and other Pseudomonas species
}

\author{
Caterina Guasp, ${ }^{1}$ Edward R. B. Moore, ${ }^{2}$ Jorge Lalucat ${ }^{1}$ \\ and Antonio Bennasar ${ }^{2}$
}

\begin{abstract}
Author for correspondence: Caterina Guasp. Tel: +34 971 173335. Fax: + 34971173184 e-mail: dbacgm4@clust.uib.es
\end{abstract}

1 Microbiologia, Departament de Biologia, Institut Mediterrani d'Estudis Avançats (CSICUIB), Palma de Mallorca, Spain

2 Mikrobiologie, Gesellschaft für Biotechnologische Forschung, Braunschweig, Germany

\begin{abstract}
Bacteria identified and classified as Pseudomonas stutzeri, on the basis of traditional criteria, are recognized to be markedly heterogeneous, such that a systematic phenotypic characterization has not been correlated with genotypic groupings (i.e. genomovars) based upon DNA-DNA similarities. The internally transcribed 16S-23S rDNA spacer (ITS1) regions of $P$. stutzeri were analysed with respect to the ability of these nucleic acid regions to differentiate and identify the genomic groups (i.e. genomovars) of $P$. stutzeri. The ITS1s of 34 strains of $P$. stutzeri were amplified by PCR and the PCR product was subjected to RFLP analysis, which allowed the differentiation and identification of the strains to their respective genomovars. Sequence determination and analysis of ITS1s supported further the results obtained by RFLP, i.e. nucleotide signatures were identified in strains belonging to different genomovars. The ITS1s of all strains of $P$. stutzeri contained the tandem tRNA"le/tRNA ${ }^{\text {Ala }}$ genes and did not exhibit distinct sequence heterogeneity between different operons of a strain. Phylogenetically informative variable sites were located, exclusively, in non-coding regions. The results of the RFLP and sequence analysis of ITS1s supported and correlated with the phylogenetic relationships estimated from 165 rRNA gene sequence comparisons and DNA-DNA hybridizations, offering an alternative tool for genomovar and species differentiation.
\end{abstract}

Keywords: $16 \mathrm{~S}-23 \mathrm{~S}$ internally transcribed spacer region, genomovar, DNA-DNA hybridization, 16S rRNA gene sequencing, RFLP fingerprinting

\section{INTRODUCTION}

Pseudomonas stutzeri is a motile, non-fluorescent, denitrifying, Gram-negative, rod-shaped bacterium. Characteristically, $P$. stutzeri is able to use maltose and starch as sole carbon and energy sources. P. stutzeri is distributed widely in the environment and has been isolated as an opportunistic pathogen from humans (Holmes, 1986). Some strains of the species have received particular attention because of specific metabolic properties, e.g. denitrification under anaerobic growth conditions (Zumft, 1992) and the degradation of aromatic compounds (Rosselló-Mora et al., 1994)

The EMBL accession numbers are given in Table 1. and high-molecular-mass polyethylene glycols (Obradors \& Aguilar, 1991). Furthermore, some strains of $P$. stutzeri have been shown to be naturally transformable and have been studied extensively for their capacities for transformation (Carlson et al., 1983; Stewart \& Sinigalliano, 1991; Lorenz \& Wackernagel, 1994; Sikorski et al., 1998).

Studies have shown that $P$. stutzeri, as a species, possesses a high degree of phenotypic and genotypic heterogeneity (Stanier et al., 1966; Palleroni et al., 1970; Rosselló et al., 1991). Eight genomic groups, based upon DNA-DNA hybridization similarities, termed 'genomovars', have been proposed (Rosselló et al., 1991; Rosselló-Mora et al., 1996). Phenotypic characteristics have not been determined to allow a 
systematic discrimination of the genomic groups for differentiating and proposing new species. Only one of the described $P$. stutzeri genomovars has been reclassified and validly published, as the new species Pseudomonas balearica (Bennasar et al., 1996). Thus because of the phenotypic heterogeneity existing among strains of $P$. stutzeri species, DNA similarity, as measured by DNA-DNA reassociation experiments (Johnson, 1973; Johnson \& Palleroni, 1989; Wayne et al., 1987), has been the standard genotypic method for assigning a strain to a given genomovar (Rosselló et al., 1991). Although 16S rRNA gene sequence comparisons have provided insight into the natural relationships among the genomovars and have further supported the genomovar concept (the sequence similarities of $16 \mathrm{~S}$ rRNA genes between members of the same genomovar are 99.9-100\%) (Bennasar et al., 1996; Rosselló-Mora et al., 1996), the 16S rRNA gene sequences of $P$. stutzeri, alone, do not provide sufficient resolution of all genomovars (the similarities of $16 \mathrm{~S}$ rRNA gene sequences between strains of different genomovars range from 98.0 to $99.7 \%$ ) (Bennasar et al., 1996).

In spite of the high degree of conservation of rRNA (and rRNA genes), the degree of nucleotide variance among rRNA sequences is, generally, large enough to be used for estimating relationships across the phylogenetic spectrum of bacteria (Gutell et al., 1994). However, in some cases, the sequences of $16 \mathrm{~S}$ rRNA genes have been shown to be very similar between different species within a genus, making it desirable to find alternative specific sequences for closely related genomic groups, such as the case of genomovars of $P$. stutzeri and others (Manceau \& Horvais, 1997; Mendoza et al., 1998; Pérez-Luz et al., 1998; Vaneechoutte et al., 1998; Yoon et al., 1998). The intergenic $16 \mathrm{~S}-23 \mathrm{~S}$ internally transcribed spacer (ITS1) regions are assumed to be less susceptible to selection pressure, because of their non-coding function, and should have accumulated a higher percentage of mutations than the rRNA genes (Tyrrell et al., 1997). The analysis and comparison of sequences of ITS1s from different bacteria indicate that considerable variation in length and primary sequence occurs (Gürtler \& Stanisich, 1996) and that they may be good candidates to be used as markers for discriminating between closely related taxa, e.g. genomovars (Barry et al., 1991; Jensen et al., 1993; Gürtler \& Stanisich, 1996; Leblond-Bourget et al., 1996; Pérez-Luz et al., 1998; Riffard et al., 1998).

The aim of the present work was to examine the ITS1 regions and their value for differentiating and identifying $P$. stutzeri genomovars, specifically, and, in general, their potential for defining bacterial species.

\section{METHODS}

Bacterial strains. The strains used in this study and their sources of isolation are presented in Table 1. Environmental isolates from samples obtained at different times and places were used. The environmental strains were identified previously, using conventional phenotypic characterization (Palleroni, 1984) and specific PCR amplification (Bennasar et al., 1998a). A total of seven P. stutzeri clinical strains, isolated from patients at different times from geographically diverse sources, were examined. The clinical isolates had been classified previously as presumptive $P$. stutzeri by routine testing using API 20NE (bioMérieux), and specific PCR. All strains were grown on LB agar medium at $30^{\circ} \mathrm{C}$.

Approximately one-third (i.e. the $5^{\prime}$-end) of the PCRamplified 16S rRNA genes from the different strains were sequenced, using the primer 16R518 (5'-CGTATTACCGCGGCTGCTGG-3') and the protocols described by Abraham et al. (1999), in order to confirm the preliminary identifications (Table 2).

DNA-DNA hybridizations. Genomic DNA from bacterial strains was isolated following the method of Marmur (1961). DNA-DNA hybridizations were performed using a modification of the hydroxyapatite method described previously (Ziemke et al., 1998). Reference DNAs were double-labelled with DIG-11-dUTP and Biotin-16-dUTP, using the NickTranslation kit (Boehringer Mannheim) and instructions of the manufacturer.

PCR amplification of ITS1. A single bacterial colony from a fresh culture was resuspended in $100 \mu$ sterile TE buffer (10 mM Tris, $1 \mathrm{mM}$ EDTA, pH 8.0). The cell suspension was boiled for $10 \mathrm{~min}$, centrifuged for $5 \mathrm{~min}$ at $14000 \mathrm{~g}$ and $1 \mu 1$ of the resulting supernatant was used for PCR (Moore et al., 1999). The ITS1 was amplified by PCR with oligonucleotide primers 16F945 and 23R458 (Lane et al., 1985), designed to anneal to conserved positions in the $3^{\prime}$ and $5^{\prime}$ regions of the bacterial $16 \mathrm{~S}$ rRNA and $23 \mathrm{~S}$ rRNA genes, respectively. Primers 16F945 (5'-GGG CCC GCA CAA GCG GTG G-3') and 23R458 (5'-CTT TCC CTC ACG GTA C-3') targeted positions 927-945 of the Escherichia coli 16S rRNA gene (Brosius et al., 1978) and positions 458-473 of the E. coli 23S rRNA gene (Brosius et al., 1980), respectively.

PCRs were carried out in $100 \mu 1$ reaction volumes containing $10 \mathrm{mM}$ Tris/ $/ \mathrm{HCl} \mathrm{pH} \mathrm{9.0,} 1.5 \mathrm{mM} \mathrm{MgCl}_{2}, 50 \mathrm{mM} \mathrm{KCl}$, $200 \mu \mathrm{M}$ of each of the four deoxyribonucleoside triphosphates (Pharmacia Biotech), 0.5 $\mu \mathrm{M}$ forward and reverse primers, $1 \mu \mathrm{l}$ template DNA and 2.5 U Amplitaq DNA polymerase (Perkin-Elmer Cetus). The reactions were performed in a PE9600 (Perkin-Elmer Cetus GeneAmp) thermocycler, with an initial denaturation of $5 \mathrm{~min}$ at $94^{\circ} \mathrm{C}$, followed by 30 cycles of $1 \mathrm{~min}$ at $94{ }^{\circ} \mathrm{C}, 1 \mathrm{~min}$ at $55^{\circ} \mathrm{C}$ and 2 min at $72{ }^{\circ} \mathrm{C}$. Following amplifications, samples were incubated at $72{ }^{\circ} \mathrm{C}$ for $10 \mathrm{~min}$ and then cooled to $4{ }^{\circ} \mathrm{C}$. PCR products were analysed by electrophoresis in 1.5\% agarose and stained with ethidium bromide.

RFLP of ITS1. The ITS1 amplicons were treated with $1 \mathrm{U}$ TaqI, AluI, HaeIII, DraI or BclI restriction endonucleases (Boehringer Mannheim), following the instructions of the manufacturer, to determine the characteristic RFLP for each strain. After incubation, the resulting fragments were separated by electrophoresis in a 3\% agarose (NuSieve 3:1 agarose; FMC BioProducts) gel in TBE ( $89 \mu \mathrm{M}$ Tris, $88 \mu \mathrm{M}$ boric acid, $2 \mu \mathrm{M}$ EDTA) buffer and stained with ethidium bromide.

RFLP cluster analysis of ITS1. An image analysis system (Whole Band Analyser; Bioimage) was used for calculating similarities between all possible RFLP restriction fragment pair comparisons and for cluster analysis from the generated 
Table 1. Strains used in this study

\begin{tabular}{|c|c|c|c|}
\hline Species or isolate* & Strain designation $\dagger$ & $\begin{array}{l}\text { ITS1 EMBL } \\
\text { accession no. }\end{array}$ & Source \\
\hline Pseudomonas stutzeri gv. $1 \dagger$ & CCUG $11256^{\mathrm{T}}$ & AJ 251910 & $\begin{array}{l}\text { Clinical isolate (Copenhagen, Denmark, } \\
\text { before 1966) }\end{array}$ \\
\hline Pseudomonas stutzeri gv. 1 & ATCC 17594 & AJ251900 & Clinical isolate \\
\hline Pseudomonas stutzeri gv. $2 \ddagger$ & ATCC 17591 & AJ 251901 & $\begin{array}{l}\text { Clinical isolate (Copenhagen, Denmark, } \\
\text { 1956) }\end{array}$ \\
\hline Pseudomonas stutzeri gv. 2 & ATCC 17587 & AJ 251902 & $\begin{array}{l}\text { Clinical isolate (Copenhagen, Denmark, } \\
\text { 1956) }\end{array}$ \\
\hline Pseudomonas stutzeri gv. $3 \ddagger$ & DSM 50227 & AJ251903 & Clinical isolate \\
\hline Pseudomonas stutzeri gv. 3 & AN 10 & AJ 251904 & Marine isolate (Barcelona, Spain, 1982) \\
\hline Pseudomonas stutzeri gv. 3 & AN 11 & AJ251905 & Marine isolate (Barcelona, Spain, 1982) \\
\hline Pseudomonas stutzeri gv. $4 \uparrow$ & 19SMN4 & AJ251906 & Marine isolate (Barcelona, Spain, 1988) \\
\hline Pseudomonas stutzeri gv. 4 & ST27MN3 & AJ251907 & Marine isolate (Barcelona, Spain, 1988) \\
\hline Pseudomonas stutzeri gv. $5 \ddagger$ & DNSP21 & AJ251908 & Wastewater isolate (Mallorca, Spain, 1988) \\
\hline Pseudomonas balearica gv. $6 \$ \S$ & DSM $6083^{T}$ & AJ 279238 & Wastewater isolate (Mallorca, Spain, 1988) \\
\hline Pseudomonas balearica gv. $6 \S$ & LS401 & AJ279239 & Marine isolate (Barcelona, Spain, 1988) \\
\hline Pseudomonas stutzeri gv. $7 \ddagger$ & DSM 50238 & AJ251909 & $\begin{array}{l}\text { Soil isolate (Berkeley, California, before } \\
\text { 1966) }\end{array}$ \\
\hline Pseudomonas stutzeri gv. $8 \ddagger$ & JM 300 & AJ390581 & Soil isolate (California, before 1982) \\
\hline Pseudomonas aeruginosa & CCM $1960^{\mathrm{T}}$ & L28148 & \\
\hline Pseudomonas putida & DSM $50202^{\mathrm{T}}$ & & Lactate enrichment \\
\hline Pseudomonas fragi & CECT $446^{\mathrm{T}}$ & AJ279241 & \\
\hline Pseudomonas chlororaphis & DSM $50083^{\mathrm{T}}$ & AJ 279240 & Plate contaminant \\
\hline Pseudomonas cichorii & DSM $50259^{\mathrm{T}}$ & AJ279242 & \\
\hline Pseudomonas syringae & LMG $1247^{\mathrm{T}}$ & D86356 & \\
\hline Pseudomonas agarici & LMG $2112^{\mathrm{T}}$ & AJ279243 & Cultivated mushroom \\
\hline Pseudomonas tolaasii & LMG $2342^{\mathrm{T}}$ & $\mathrm{AJ} 279244$ & Cultivated mushroom \\
\hline Pseudomonas asplenii & LMG $2137^{\mathrm{T}}$ & & \\
\hline Pseudomonas mendocina & ATCC $25411^{\mathrm{T}}$ & L28159 & Soil \\
\hline Pseudomonas pseudoalcaligenes & ATCC $17440^{\mathrm{T}}$ & AJ279245 & Sinus drainage \\
\hline Pseudomonas alcaligenes & LMG $1224^{\mathrm{T}}$ & & \\
\hline Pseudomonas stutzeri & SADN 19 & AJ390582 & Brackish water (Mallorca, Spain, 1993) \\
\hline Pseudomonas stutzeri & SD55473 & AJ390583 & Clinical isolate \\
\hline Pseudomonas stutzeri & SD93936 & AJ390584 & Clinical isolate \\
\hline Pseudomonas stutzeri & AER 2.5 & AJ390585 & $\begin{array}{l}\text { Aircraft-oil-contaminated soil (Mallorca, } \\
\text { Spain, 1995) }\end{array}$ \\
\hline Pseudomonas stutzeri & AER 2.7 & AJ390586 & $\begin{array}{l}\text { Aircraft-oil-contaminated soil (Mallorca, } \\
\text { Spain, 1995) }\end{array}$ \\
\hline Pseudomonas stutzeri & AER 5.1 & AJ390587 & $\begin{array}{l}\text { Aircraft-oil-contaminated soil (Mallorca, } \\
\text { Spain, 1995) }\end{array}$ \\
\hline Pseudomonas stutzeri & JD4 & AJ390588 & Garden soil (Mallorca, Spain, 1995) \\
\hline Pseudomonas stutzeri & PII1 & AJ390589 & Wastewater (Mallorca, Spain, 1996) \\
\hline Pseudomonas stutzeri gv. 2 & ATCC 14405 ZoBell & AJ390590 & Marine \\
\hline
\end{tabular}

* gv., genomovar (Rosselló et al., 1991).

$\uparrow$ CCUG, Culture Collection of the University of Göteborg, Göteborg, Sweden; ATCC, American Type Culture Collection, Manassas, VA; DSM, Deutsche Sammlung von Mikroorganismen und Zellkulturen, Braunschweig, Germany; CCM, Czechoslovak Collection of Microorganisms, Brno, Czechoslovakia; CECT, Colección Española de Cultivos Tipo, Valencia, Spain; LMG, Laboratorium Microbiologie Rijksuniversiteit, Gent, Belgium.

+ Type strain of genomovar.

$\S$ Genomovar reclassified as P. balearica (Bennasar et al., 1996).

matrix of similarity values. Dendrograms of relationships were deduced by the unweighted pair group method with averages (UPGMA) cluster algorithm.
Nucleotide sequence determination of ITS1. PCR-amplified ITS1 regions were purified using Microcon-100 concentrators (Amicon) and sequenced directly, using an Applied 
Table 2. Nucleotide signatures identified for each genomovar, on the basis that each nucleotide signature position is conserved only for those strains belonging to the same genomovar

Signature positions for the corresponding genomovars are indicated in bold. gv., genomovar; -, gaps in the alignment of ITS1 sequences.

\begin{tabular}{|c|c|c|c|c|c|c|c|}
\hline Position* & gv. 1 & gv. 2 & gv. 3 & gv. 4 & gv. 5 & gv. 7 & gv. 8 \\
\hline 26 & $\mathrm{~T}$ & $\mathrm{~T}$ & $\mathrm{~T}$ & $\mathrm{~T}$ & $\mathrm{~T}$ & $\mathrm{~T}$ & $\mathbf{G}$ \\
\hline 31 & C & $\mathbf{T}$ & C & C & C & C & $\mathrm{C}$ \\
\hline 33 & $\mathrm{~T}$ & C & $\mathrm{T}$ & $\mathrm{T}$ & $\mathrm{T}$ & $\mathrm{T}$ & $\mathrm{T}$ \\
\hline 34 & A & A & A & A & A & A & G \\
\hline 38 & $\mathrm{~T}$ & $\mathrm{~T}$ & $\mathrm{~T}$ & $\mathrm{~T}$ & $\mathrm{~T}$ & $\mathrm{~T}$ & G \\
\hline 63 & $\mathrm{~T}$ & A & A & A & $\mathrm{T}$ & $\mathrm{T}$ & G \\
\hline 66 & $\mathrm{G}$ & $\mathrm{G}$ & $\mathrm{G}$ & $\mathrm{G}$ & G & G & $\mathbf{T}$ \\
\hline 314 & $\mathrm{~T}$ & $\mathbf{A}$ & $\mathrm{T}$ & $\mathrm{T}$ & $\mathrm{T}$ & $\mathrm{T}$ & $\mathrm{T}$ \\
\hline 329 & $\mathrm{~T}$ & C & $\mathrm{G}$ & $\mathrm{G}$ & $\mathrm{T}$ & $\mathrm{T}$ & $\mathrm{T}$ \\
\hline 332 & C & G & $\mathrm{T}$ & $\mathrm{T}$ & C & A & $\mathrm{T}$ \\
\hline 334 & $\mathrm{G}$ & $\mathrm{G}$ & C & $\mathrm{G}$ & $\mathrm{G}$ & G & A \\
\hline 339 & A & $\mathbf{G}$ & C & C & A & C & - \\
\hline 343 & $\mathrm{~T}$ & - & $\mathrm{T}$ & C & $\mathrm{T}$ & G & - \\
\hline 351 & C & - & G & $\mathbf{T}$ & C & - & - \\
\hline 356 & $\mathbf{T}$ & - & - & - & A & - & - \\
\hline 358 & $\mathrm{G}$ & $\mathrm{G}$ & $\mathrm{G}$ & $\mathrm{G}$ & G & A & $\mathrm{G}$ \\
\hline 380 & C & C & C & C & C & - & $\mathbf{T}$ \\
\hline 400 & A & A & A & A & C & A & A \\
\hline 431 & A & G & A & A & A & $\mathbf{T}$ & A \\
\hline 432 & $\mathrm{~T}$ & $\mathrm{G}$ & $\mathrm{G}$ & $\mathrm{G}$ & $\mathrm{T}$ & $\mathrm{T}$ & $\mathbf{A}$ \\
\hline 433 & $\mathrm{G}$ & $\mathrm{T}$ & $\mathrm{T}$ & $\mathrm{T}$ & $\mathrm{G}$ & C & $\mathrm{T}$ \\
\hline 434 & $\mathrm{~T}$ & $\mathbf{A}$ & $\mathrm{G}$ & $\mathrm{G}$ & $\mathrm{T}$ & $\mathrm{G}$ & $\mathrm{G}$ \\
\hline 437 & $\mathrm{~T}$ & $\mathrm{~T}$ & C & $\mathrm{C}$ & $\mathrm{T}$ & C & $\mathbf{G}$ \\
\hline 438 & $\mathrm{G}$ & A & A & A & $\mathrm{G}$ & A & $\mathbf{T}$ \\
\hline 439 & C & C & C & C & C & $\mathbf{T}$ & C \\
\hline 448 & $\mathrm{G}$ & $\mathrm{G}$ & $\mathrm{G}$ & $\mathrm{G}$ & $\mathrm{G}$ & A & $\mathrm{G}$ \\
\hline 449 & $\mathrm{C}$ & $\mathrm{T}$ & $\mathrm{T}$ & $\mathrm{T}$ & C & $\mathrm{T}$ & $\mathbf{G}$ \\
\hline 450 & A & A & $\mathrm{G}$ & $\mathrm{G}$ & A & $\mathrm{G}$ & C \\
\hline 456 & $\mathrm{G}$ & $\mathrm{T}$ & $\mathrm{T}$ & $\mathrm{T}$ & $\mathrm{G}$ & $\mathbf{A}$ & $\mathrm{T}$ \\
\hline 458 & C & C & C & $\mathrm{C}$ & C & $\mathbf{T}$ & C \\
\hline 460 & $\mathrm{C}$ & A & A & A & C & G & C \\
\hline 481 & $\mathrm{G}$ & $\mathrm{G}$ & $\mathrm{G}$ & $\mathrm{G}$ & $\mathrm{G}$ & A & G \\
\hline 483 & $\mathrm{~T}$ & $\mathrm{~T}$ & $\mathrm{~T}$ & A & $\mathrm{T}$ & $\mathrm{T}$ & $\mathrm{T}$ \\
\hline 495 & - & C & - & A & - & C & C \\
\hline 498 & - & - & - & $T$ & - & G & $\mathbf{A}$ \\
\hline
\end{tabular}

* Numbering with respect to the ribosome-binding site ( 3 '-end of the $16 \mathrm{~S}$ rRNA gene).

Biosystems 373A DNA sequencer and the protocols of the manufacturer (Perkin-Elmer, Applied Biosystems Division) for ' $T a q$ cycle-sequencing' with fluorescent-dye-labelled dideoxynucleotides. The primers used for sequencing were rrn16S (5'-GAA GTC GTA ACA AGG-3') and rrn23S (5'CAA GGC ATC CAC C-3') (Jensen et al., 1993), targeting the $3^{\prime}$ - and 5 '-ends of the $16 \mathrm{~S}$ and $23 \mathrm{~S}$ rDNAs, positions 1491-1505 and 21-35, respectively. All oligonucleotides were purchased from Pharmacia Biotech. Nucleotide sequence accession numbers are included in Table 1.
In cases where more than one amplified ITS1 product for a strain was detected, the individual ITS1s were PCR-amplified with $\operatorname{rrn} 16 \mathrm{~S}$ and $\operatorname{rrn} 23 \mathrm{~S}$ primers, and separated by electrophoresis in pre-cast non-denaturing polyacrylamide gels (CleanGel DNA Analysis kit; Pharmacia Biotech) on a horizontal Multiphor II electrophoresis unit, with a pre-run at $200 \mathrm{~V}$ for $10 \mathrm{~min}$, followed by $45 \mathrm{~min}$ at $600 \mathrm{~V}$. After electrophoresis, the gels were stained using the Plus One Silver Staining kit (Pharmacia Biotech) and following the protocols of the manufacturer. Separated bands were excised from the gel and the DNA was eluted from the acrylamide, to be used as template for the regeneration of the ITS1 by PCR, using primers rrn16S and rrn23S. Amplicons from these PCRs were sequenced directly after purification as described above.

Nucleotide sequence analysis of ITS1. ITS1 nucleotide sequences were aligned using the computer program CLUSTAL W (Thompson et al., 1994) with a final manual adjustment (Rambaut, 1996). Percentage similarities between the ITS1 regions of different strains were determined after the corresponding $16 \mathrm{~S}$ and $23 \mathrm{~S}$ rRNA and tRNA gene sequence regions were omitted. Evolutionary distances (Jukes \& Cantor, 1969) were calculated from pairwise sequence similarities and estimations of relationships were generated using the Fitch program within the Phylogeny Inference Package (PHYLIP) (Felsenstein, 1989).

\section{RESULTS AND DISCUSSION}

\section{PCR amplification of ITS1}

In the present study, the ITS1s of 34 strains, including representative strains of each described genomovar, as well as new isolates of $P$. stutzeri and type strains of other Pseudomonas species, were successfully amplified by PCR. Amplicons of nearly $1550 \mathrm{bp}$ in length were calculated to comprise approximately $550 \mathrm{bp}$ of the $3^{\prime}$ portion of the 16S rRNA gene, the ITS1 and $455 \mathrm{bp}$ of the 5' portion of the 23S rRNA gene. A single band of the same size, as seen after agarose gel electrophoresis, was obtained from all strains of $P$. stutzeri and from Pseudomonas aeruginosa, Pseudomonas alcaligenes and Pseudomonas tolaasii. The PCR-ITS1 amplification products of Pseudomonas putida (3), Pseudomonas fluorescens (3), Pseudomonas agarici (3), Pseudomonas fragi (3), Pseudomonas mendocina (3), Pseudomonas syringae (3) and Pseudomonas chlororaphis (2) comprised 2 or 3 bands (number in parentheses) of lengths of $1500-1600 \mathrm{bp}$ (data not shown). Although differences were observed in the number and size of the PCR-ITS1 products obtained from different species, these characteristics alone could not be used for a general differentiation of all P. stutzeri genomovars or Pseudomonas species.

Single-strand conformational polymorphism electrophoresis, in comparison with simple agarose gel electrophoretic analysis, has been shown previously to resolve some PCR-ITS1 products of $P$. stutzeri strains on the basis of their sequence heterogeneities (Bennasar et al., 1998b). However, in order to differentiate each genomovar of $P$. stutzeri, higher-resolution methods are needed. 
(a)
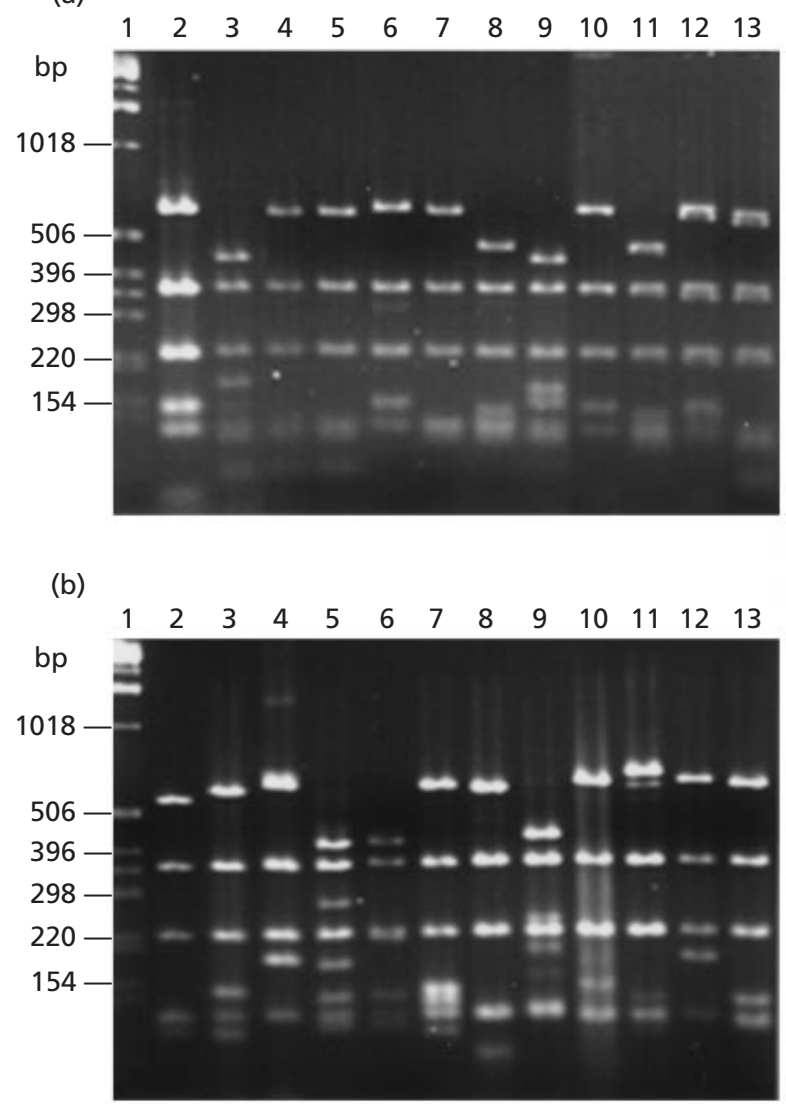

Fig. 1. Agarose gel showing the Taql restriction products of PCR-ITS1. (a) P. stutzeri genomovars (including $P$. balearica): 1, molecular mass marker $1 \mathrm{~kb}$ (Gibco-BRL); 2, CCUG $11256^{\top}$ gv. 1; 3, ATCC 17591 gv. 2; 4, DSM 50227 gv. 3; 5, 19SMN4 gv. 4; 6, DNSP21 gv. $5 ; 7$, SP1402 ${ }^{\top}=$ DSM $6083^{\top}$ gv. $6 ; 8$, DSM 50238 gv. 7; 9, JM300 gv. 8; 10, AER2.5; 11, AER2.7; 12, JD4; 13, AER5.1. (b) Pseudomonas species: 1, molecular mass marker $1 \mathrm{~kb}$ (GibcoBRL); 2, P. aeruginosa CCM $1960^{\top} ; 3$, P. alcaligenes LMG $1224^{\top}$; 4, P. mendocina ATCC $25411^{\top} ; 5$, P. fluorescens DSM 50090 $; 6$, P. tolaasii LMG $2342^{\top} ; 7$, P. chlororaphis DSM 50083 $; 8$, Pseudomonas cichorii DSM 50259 $;$; , P. putida DSM 50202 ${ }^{\top} ; 10$, P. agarici $\mathrm{LMG} 2112^{\top}$; 11 , P. fragi $\mathrm{CECT}^{\top}$; 12 , Pseudomonas pseudoalcaligenes ATCC $17440^{\top} ; 13$, Pseudomonas asplenii LMG $2137^{\top}$. gv., genomovar.

\section{RFLP and cluster analysis of ITS1}

Three enzymes recognizing four-nucleotide restriction sites, with expected high restriction frequencies, $\operatorname{Taq} \mathrm{I}$, $A l u \mathrm{I}$ and HaeIII, were selected and applied for RFLP analysis. The enzymes $T a q \mathrm{I}$ and $A l u \mathrm{I}$ produced as many as six different restriction profiles for the $P$. stutzeri strains tested. However, HaeIII was able to distinguish only genomovar $6(P$. balearica) from the other genomovars. The TaqI restriction profiles of the ITS1 amplicons, using the PCR primers 16F945 and 23R 458, comprised four to seven bands of sizes ranging from $75 \mathrm{bp}$ to $650 \mathrm{bp}$ (Fig. 1). In all cases, identical $T a q$ I digestion profiles were obtained for strains belonging to a given genomovar (as defined by genomic DNA similarities). All P. stutzeri genomovars pre-

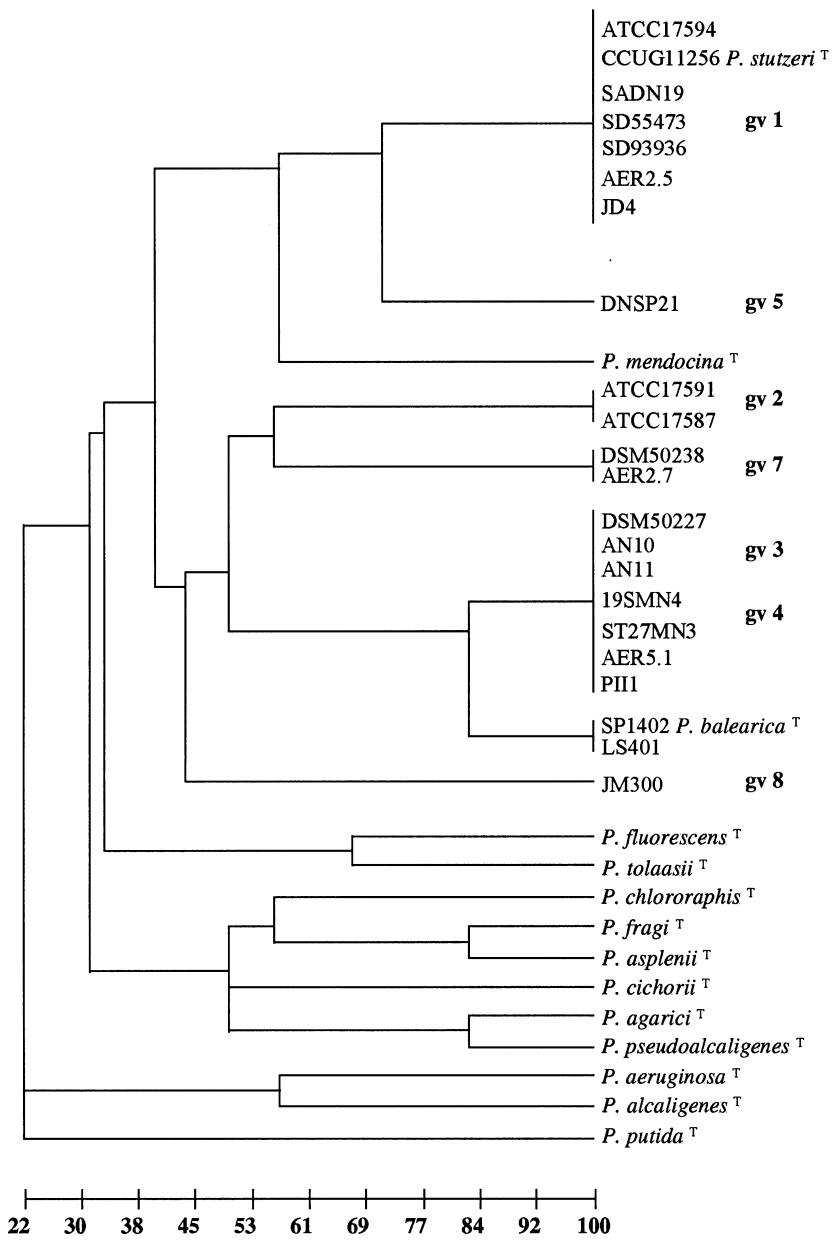

Fig. 2. UPGMA clustering of $P$. stutzeri strains and other species of Pseudomonas based on Taql RFLP of PCR-ITS1. P. stutzeri is indicated by strain numbers.

sented two characteristic bands of 360 and $230 \mathrm{bp}$ in their TaqI restriction patterns, while other bands of the restriction patterns allowed differentiation of genomovars (Fig. 1). Strain JD4 of genomovar 5 displayed an identical TaqI restriction pattern to that of strains of genomovar 1, as also the strains of genomovars 3 and 4 exhibited an identical RFLP pattern.

The ITS1 restriction patterns of strains of $P$. stutzeri and other species of Pseudomonas, generated by TaqI digestion, were clustered by UPGMA (Fig. 2). Branching dichotomies, due to ITS1 polymorphisms, resulted in clusters of strains at the species level (Fig. 2). Interestingly, P. mendocina was observed to cluster within the spectrum of $P$. stutzeri genomovars. $P$. stutzeri strains belonging to the same genomovar were observed to group within distinct, robust clusters, with the exception of strain JD4, which clustered with the strains of genomovar 1, and strains of genomovars 3 and 4 , which were not resolved.

In order to obtain profiles of higher resolving power, due to the discrepancies observed with respect to strain 


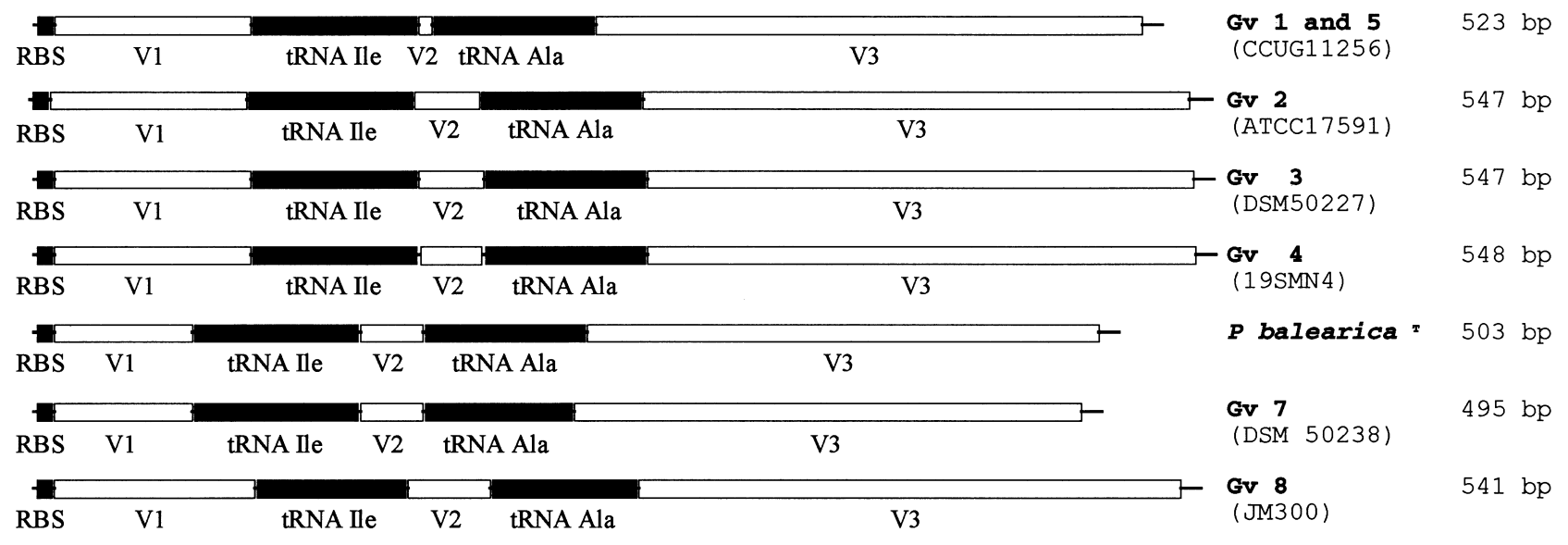

Fig. 3. Organization of the ITS1 region of $P$. stutzeri genomovars and $P$. balearica DSM $6083^{\top}$. tRNA ${ }^{l l e}$ and tRNA $A^{A l a}$ genes (black) are arranged in tandem. Regions V1, V2 and V3, between the 165 rRNA-tRNA ${ }^{\text {lle }}$, tRNA ${ }^{\text {lle }}$-tRNA ${ }^{\text {Ala }}$ and tRNA ${ }^{\text {Ala }}-235$ rRNA genes, respectively, are highly variable (white). RBS, ribosome-binding site (Shine \& Dalgarno, 1974).

JD4 and genomovar 1 and genomovars 3 and 4, additional restriction enzymes were tested. The PCRITS1 amplicons of genomovars 3 and 4 (which could not be distinguished by $T a q \mathrm{I}$ restriction patterns) were digested and resolved by $B c l$ I digestion. A pattern of two bands of approximately $1000 \mathrm{bp}$ and $550 \mathrm{bp}$ was generated for genomovar 4. The PCR-amplified ITS1s of the other genomovars were not cut by $B c l$ I (data not shown). Of other species of Pseudomonas analysed, only the ITS1 of $P$. aeruginosa presented the same $B c l$ I band pattern as that observed for genomovar 4 .

\section{Nucleotide sequence determination and analysis of ITS1}

While TaqI RFLP analysis of $P$. stutzeri strains provided, in most cases, differentiation at the genomovar level and differentiation of Pseudomonas at the species level, the observed cases which were not resolved indicated that an even finer resolution may be possible to attain, e.g. through sequence determinations.

The $P$. stutzeri genome contains four rRNA transcriptional units ( $r r n A, B, C, D)$ at different chromosomal locations (Ginard et al., 1997). The rRNA operon of $P$. stutzeri strain ZoBell (ATCC 14405) was cloned and characterized by sequence analysis (Kerkhof, 1997) and it was observed to exhibit the typical bacterial organization of the following components in the order: 5'-16S rRNA gene-ITS1-23S rRNA gene-ITS2-5S rRNA gene-3'. The PCRamplified ITS1s of this study were sequenced directly using the ITS1 flanking primers $\operatorname{rrn} 16 \mathrm{~S}$ and $\operatorname{rrn} 23 \mathrm{~S}$ (Jensen et al., 1993). The lengths of the ITS1 regions of the strains of $P$. stutzeri studied ranged from 495 to 548 bp (Fig. 3), from the 3'-end of the ribosome-binding site (Shine \& Dalgarno, 1974) to the identified 5'-end of the 23S rRNA gene (Kerkhof, 1997). Strains of a genomovar were observed to possess nearly identical ITS1 sequences, with two or three observed nucleotide differences, suggesting that only random micro-heterogeneities exist between strains of a genomovar of $P$. stutzeri, as has been described for other species (Gürtler \& Stanisich, 1996). Eight distinct sequence types with respect to length and nucleotide composition were observed, i.e. one for each genomovar of $P$. stutzeri, although genomovars 1 and 5 are very similar, and ITS1 signature positions for each genomovar have been identified (Table 2).

All analysed strains of Pseudomonas species shared identical nucleotide sequences immediately adjacent to the $3^{\prime}$ - and $5^{\prime}$-ends of the $16 \mathrm{~S}$ and $23 \mathrm{~S}$ rRNA genes, respectively. The ITS1 of all strains of $P$. stutzeri, as well as strains of the other species of Pseudomonas analysed (except one strain of $P$. putida), contained tRNA (i.e. tRNA $^{\text {Ile }}$ and tRNA ${ }^{\mathrm{Ala}}$ ) genes, as has been reported for most Gram-negative bacteria. The tRNA genes within the ITS1 were observed to be arranged in tandem and located at nucleotide positions (counting from the ribosome-binding site) 76-104 to 187-211, depending on the genomovar (Fig. 3). Comparison of the nucleotide sequences of the tRNA ${ }^{\mathrm{Ile}} / \mathrm{tRNA}^{\mathrm{Ala}}$ genes revealed $100 \%$ identity between the respective genes for all $P$. stutzeri strains analysed. Putative secondary structures of the tRNAs, derived from the primary sequences, suggested that the tRNAs formed the characteristic 'cloverleaf' structure (Fuller \& Hodgson, 1967; Sprinzl et al., 1998). The trinucleotide 3 '-end acceptor sequence CCA, normally present, as well, in mature tRNAs, was observed in both tRNA genes (Berg et al., 1989; Srivastava \& Schlessinger, 1990).

Comparisons of aligned ITS1 sequences revealed that rRNA processing motifs are highly conserved within the ITS1 regions of all $P$. stutzeri genomovars, with hypervariable sequence regions located within the noncoding regions. In the sequence region between the tRNA genes, the number of nucleotide positions varied from 7 (in genomovars 1 and 5) to 31 (genomovars 2, 


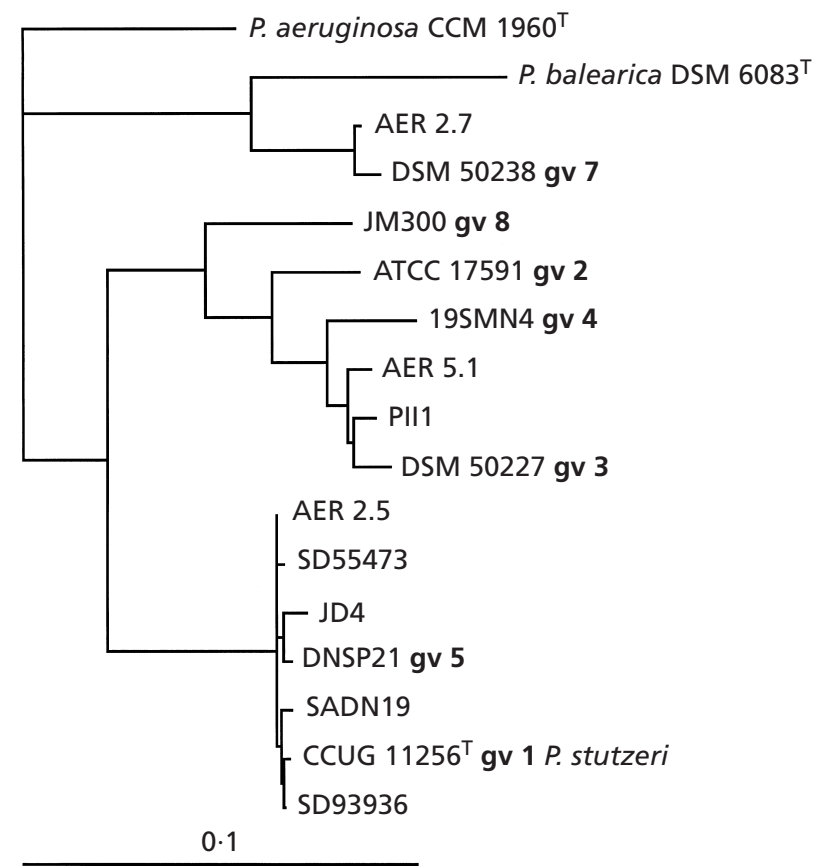

Fig. 4. Dendrogram, derived from calculated evolutionary distances, depicting the estimated evolutionary relationships between the ITS1 sequences of genomovars of $P$. stutzeri. Sequences for tRNA genes were removed from the calculations. The branch scale bar indicates a mean of 10 substitutions at any given nucleotide position per 100 positions.

3, 4 and 8) and, also, downstream from the tRNA Ala gene a high degree of sequence heterogeneity was observed. Within these hypervariable regions, insertions and deletions of blocks of nucleotides were observed, as has been described previously for other species (Gürtler \& Stanisich, 1996). Theoretically, if no, or limited, selective pressure is being exerted on these regions, a high degree of variation should be expected. Presumably, the observed conservation in nucleotide sequence of some smaller segments within the variable regions is due to the conserved secondary structures which the ITS regions must assume for proper processing by RNase III of the primary transcript (Pérez-Luz et al., 1998; García-Martínez et $a l ., 1996)$. A highly conserved sequence domain of 10 nucleotides, located at nucleotide positions 392-402, within the highly variable region between the tRNA ${ }^{\text {Ala }}$ and the $23 \mathrm{~S}$ gene, containing a putative box-A-like gene sequence (Berg et al., 1989; Srivastava \& Schlessinger, 1990), was identified in all the strains analysed. Additionally, this conserved sequence domain was preceded by a region (nucleotides 285-300) which has the potential to form a hairpin loop structure and to act as a box-B-like structure for ribosomal processing genes (Berg et al., 1989; Srivastava \& Schlessinger, 1990). This domain was observed to possess a primary sequence unique for each genomovar, although the secondary structure is conserved. The conserved primary sequence regions and secondary structure formed by ITS1 during rRNA processing were considered for generating alignments.

The aligned ITS1 sequences were used to generate a dendrogram of putative relationships (Fig. 4). The inclusion or exclusion of tRNA genes did not affect the topology of the tree. In the ITS1-sequence-based tree, three primary clusters were observed: one comprising genomovars 1 and 5; one comprising genomovars 2, 3, 4 and 8; and the most divergent comprising genomovars 6 ( $P$. balearica) and 7. This overall branching order differed from that obtained by $16 \mathrm{~S}$ rRNA gene sequence comparisons (Bennasar et al., 1996; Rosselló-Mora et al., 1996), and the respective branch lengths derived from the comparison of the ITS1 sequences of different genomovars are generally greater than those generated from the 16S rRNA gene sequences (Table 3). The similarities between ITS1 sequences of strains of a genomovar, in all cases, were

Table 3. Identification of $P$. stutzeri isolates based on DNA-DNA similarity, $16 \mathrm{~S}$ rRNA gene partial sequence similarity, ITS1 sequence similarity and PCR-ITS RFLP Taql results for $P$. stutzeri isolates

\begin{tabular}{|c|c|c|c|c|c|c|c|c|c|c|}
\hline & \multicolumn{4}{|c|}{ DNA-DNA similarity $(\%)^{*}$} & \multicolumn{4}{|c|}{$\begin{array}{c}\text { Partial (first } 518 \text { bp) } 16 \mathrm{~S} \text { rDNA sequence } \\
\text { similarity (\%) with: }\end{array}$} & \multicolumn{2}{|c|}{ ITS1 } \\
\hline & $\begin{array}{c}\text { gv. I } \\
\text { ATCC } 17589\end{array}$ & $\begin{array}{c}\text { gv. III } \\
\text { DSM 50227 }\end{array}$ & $\begin{array}{c}\text { gv. V } \\
\text { DNSP21 }\end{array}$ & $\begin{array}{c}\text { gv. VII } \\
\text { DSM } 50238\end{array}$ & $\begin{array}{l}\text { CCUG } \\
11256^{\mathrm{T}}\end{array}$ & $\begin{array}{l}\text { DSM } \\
\mathbf{5 0 2 2 7}\end{array}$ & DNSP21 & $\begin{array}{r}\text { DSM } \\
50238\end{array}$ & $\begin{array}{c}\text { Sequence } \\
\text { similarity with } \\
\text { CCUG } 1^{11256}{ }^{\mathrm{T}}\end{array}$ & RFLP type \\
\hline ATCC 17589 & 100 & 43 & 45 & 40 & $100 \cdot 00$ & $95 \cdot 39$ & $99 \cdot 78$ & $98 \cdot 42$ & $100 \cdot 00$ & I \\
\hline DSM 50227 & 37 & 100 & 42 & 55 & $95 \cdot 39$ & $100 \cdot 00$ & $95 \cdot 62$ & $96 \cdot 57$ & $89 \cdot 20$ & III \\
\hline DNSP21 & 55 & 46 & 100 & 58 & $99 \cdot 78$ & $95 \cdot 62$ & $100 \cdot 00$ & $98 \cdot 65$ & $99 \cdot 23$ & $\mathrm{~V}$ \\
\hline DSM 50238 & 31 & 33 & 35 & 100 & $98 \cdot 42$ & $96 \cdot 57$ & $98 \cdot 65$ & $100 \cdot 00$ & $84 \cdot 38$ & VII \\
\hline SADN19 & 88 & NT & NT & NT & $100 \cdot 00$ & $95 \cdot 39$ & $99 \cdot 78$ & $98 \cdot 42$ & $99 \cdot 62$ & I \\
\hline SD55473 & 99 & 42 & 47 & 35 & $100 \cdot 00$ & $95 \cdot 39$ & $99 \cdot 78$ & $98 \cdot 42$ & $99 \cdot 42$ & I \\
\hline SD93936 & 73 & 48 & NT & 45 & $100 \cdot 00$ & $95 \cdot 39$ & $99 \cdot 78$ & $98 \cdot 42$ & $99 \cdot 81$ & I \\
\hline AER2.5 & 83 & NT & NT & NT & $100 \cdot 00$ & $95 \cdot 38$ & $99 \cdot 78$ & $98 \cdot 41$ & $99 \cdot 62$ & I \\
\hline AER2.7 & 26 & 21 & 27 & 95 & $99 \cdot 32$ & $95 \cdot 37$ & $99 \cdot 55$ & $98 \cdot 87$ & 84.91 & VII \\
\hline AER5.1 & 41 & 80 & NT & NT & $95 \cdot 15$ & $99 \cdot 55$ & $95 \cdot 39$ & $96 \cdot 33$ & $88 \cdot 75$ & III \\
\hline JD4 & 53 & NT & 76 & NT & $99 \cdot 78$ & $95 \cdot 62$ & $100 \cdot 00$ & 98.65 & $98 \cdot 84$ & I \\
\hline PII1 & NT & 93 & NT & NT & $99 \cdot 78$ & $100 \cdot 00$ & $95 \cdot 62$ & $96 \cdot 57$ & 88.98 & III \\
\hline Pooled standard deviation & $0 \cdot 84$ & $0 \cdot 32$ & $0 \cdot 42$ & 1.52 & & & & & & \\
\hline
\end{tabular}

* NT, Not tested; gv., genomovar. 
observed to be greater than $99 \%$, while sequence similarities of strains from different genomovars ranged from 81 to $96 \%$, except for the strains of genomovars 1 and 5, which possessed sequence similarities of $98 \cdot 8-99.6 \%$. The close taxonomic proximity, expressed by ITS1 sequence similarities, between genomovars 1 and 5 is consistent with the observed DNA-DNA reassociation values (Rosselló et al., 1991) and 16S rRNA gene sequence similarities (Bennasar et al., 1996; Rosselló-Mora et al., 1996). Genomovar 7 was observed to possess an ITS1 sequence with many differences to those of all other genomovars (Table 2). In the ITS1-based tree (Fig. 4), genomovar 7 forms a phylogenetic branch, together with $P$. balearica, clearly separated from the branches comprising other $P$. stutzeri genomovars. In fact, sequence similarities between the ITS1 of genomovar 7 and the ITS1s of all other genomovars of P. stutzeriare lower (from 81 to $84 \%$ ) than the ITS1 similarities between $P$. aeruginosa and other strains of $P$. stutzeri (from 85 to $87 \%$ ). Genomovar 7 is phenotypically (Rosselló et al., 1991) and genotypically (Bennasar et $a l ., 1996)$ the most atypical of the currently recognized $P$. stutzeri genomovars and, justifiably, should be renamed as a new species of Pseudomonas if systematically differential phenotypic characteristics could be determined.

When the ITS1 sequences of different species of Pseudomonas (sensu stricto) were analysed by clustering, the branching order was observed to differ from the estimated phylogenetic branching order obtained when 16S rRNA sequences were compared (Moore et al., 1996). Within the Pseudomonas species studied, the ITS1 sequences are, as expected, relatively similar, although sequence differences increased when other pseudomonad rRNA homology group II species (Palleroni, 1984), e.g. Burkholderia species, were included in comparisons. Sequence similarities of the ITS1 of P. stutzeri (CCUG $11256^{\mathrm{T}}$ ) with those of other species of Pseudomonas ranged from 65\% (P. stutzeri versus $P$. putida and $P$. fragi, ) to $86 \%$ ( $P$. stutzeri versus $P$. alcaligenes).

\section{Assignment of new strains to $P$. stutzeri genomovars}

Isolates of $P$. stutzeri are often not easily identified, as has been reported by Holmes (1986). Many strains of P. stutzeri, other than those belonging to genomovar 1, will not be classified properly because of the discrepancies observed between the phenotypic and genotypic analyses. Although phenotypic characterization might indicate that a strain of interest is most probably a P. stutzeri, in the case of strains belonging to genomovars other than genomovar 1, low levels of DNA similarity with the type strain of the species (CCUG 11256 ${ }^{\mathrm{T}}$, genomovar 1) would contradict such a conclusion (Table 3). When carrying out DNADNA reassociation analyses of strains suspected to be $P$. stutzeri, it is important to keep in mind that $P$. stutzeri sensu lato is, in reality, composed of at least seven genomic groups, and comprehensive DNADNA hybridization experiments should include the reference strain of each genomovar (Table 3 ).

The establishment of reliable, high-resolution, molecular-genetic-based methods would facilitate the systematic identification of $P$. stutzeri strains. However, although specific PCR primers and probes for the detection and identification of $P$. stutzeri have been described (Bennasar et al., 1998a), as the 16S rRNA gene sequences of increasing numbers of new organisms are introduced into the databases the limitations of the resolution or discriminatory abilities of these detection and identification tools are being recognized.

As the nucleotide variability observed in the ITS1 regions is seen to be of value for the identification of genomovars of $P$. stutzeri, in this study analysis of ITS1 regions, as well as DNA-DNA hybridizations and partial 16S rRNA gene sequencing, was applied to the identification of new isolates identified as $P$. stutzeri (Table 3). All new isolates were assigned to a known genomovar by DNA-DNA hybridization experiments (as a general rule, strains are considered to be in the same genomovar when percentages of DNA-DNA similarities are higher than $70 \%$, which is also the level of discrimination for bacterial species; Johnson, 1973, 1984). The results obtained by TaqI ITS1 RFLP and analysis of ITS1 sequences correlated with the assignment of each new strain to a known genomovar. Identifications determined by both methods, ITS1 RFLP and ITS1 sequence comparisons, were complementary, although ITS1 sequencing is more discriminative. These results agreed with the DNA similarity results obtained (Table 3 ).

An example of a discrepancy was observed with respect to the classification of the recently isolated strain JD4. JD4 was assigned to genomovar 5 by the results of DNA-DNA hybridizations (Table 3), as well as nearly full-length 16S rRNA gene sequence analysis. However, ITS1 RFLP analysis using restriction enzymes TaqI and DraI clustered strain JD4 with strains of genomovar 1, although ITS1 sequence similarities and cluster analysis clearly show JD4 to be most closely related to the reference strain of genomovar 5 (DNSP21). While the DNA relatedness results allocated JD4 to genomovar 5 at the lower limits (76\% DNA similarity) recognized for allocating a strain to a genomovar (approx. 70\% DNA similarity), the degree of DNA relatedness between JD4 and the reference strain of genomovar 1 (CCUG $11256^{\mathrm{T}}$ ) was significantly lower (53\% DNA similarity) (Table 3 ). Thus it is evident that, although TaqI and DraI ITS1 RFLP analyses were not able to identify strain JD4 to the genomovar corresponding to genomic DNA similarities, ITS1 sequence determination and analysis allocated this strain to the correct genomovar. Furthermore, in spite of the high similarities between the ITS1 sequences of strains of genomovars 1 and 5, comparative analysis identified signature nucleotide 
positions for each $P$. stutzeri genomovar (Table 2), including genomovars 1 and 5, which are recognized to be adequately specific to allow the design of PCR primers that react only with the respective target genomovar (Guasp, 1999).

\section{General conclusions}

Sequencing of ITS1 regions is a relatively fast (only one PCR and one sequencing reaction are required) and reliable method for the differentiation of $P$. stutzeri genomovars and the identification of new strains, and may be seen as a useful alternative to DNA-DNA hybridization. The PCR amplicon size variation, together with the nucleotide sequence divergence, of ITS1 also can be applied for identifying strains belonging to the same genomovar and for discriminating species belonging to the same genus. From the data presented, ITS1 nucleotide sequence differentiation of the P. stutzeri genomovars correlates with the DNA-DNA hybridization results. Furthermore, it is evident that if two strains have the same ITS1 sequence, or if only punctual differences are detected, they are likely to be members of the same species, i.e. the same genomovar in the case of P. stutzeri. This conclusion is in accordance as well with the results obtained by Yoon et al. (1998) for strains of the genus Nocardioides. The differences observed in dendrogram branching order and branch lengths obtained from ITS1 sequences compared with those obtained from 16S rRNA gene sequences reflect the respective different rates of evolution. Whereas comparisons of 16S rRNA gene sequences are limited in their ability to resolve closely related species of a genus (Ash et al., 1991; Fox et al., 1992; Martinez-Murcia et al., 1992; Hauben et al., 1997, 1998), the less conserved ITS1 regions are able to be used as a high-resolution indicator of the evolutionary divergence between species. Thus ITS1 regions may be good targets of genomovar- and species-specific probes for environmental monitoring.

A rapid characterization scheme at the genomovar, i.e. genomic species, level is possible based on PCR amplification and subsequent RFLP of ITS1. TaqI RFLP fingerprinting of the ITS1 is a rapid approach for characterizing, typing and identifying $P$. stutzeri strains at the genomovar level, in most cases, without the necessity of ITS1 sequencing or DNA-DNA hybridization. The combination of three ITS1 RFLP tests (TaqI, BclI and DraI) allowed a relatively conclusive genomic group differentiation of $P$. stutzeri strains, in accordance with the differentiation observed by DNA-DNA similarities. Although at least one exception was observed, and more might be expected as more strains are analysed, ultimately careful analysis of ITS1 sequence data should positively feed back to optimize additional confirmative rapid RFLP tests for confidently assigning new $P$. stutzeri strains to genomovars. The ITS PCR-RFLP method is the most rapid and least expensive way to routinely identify the phenotypically and genotypically heterogeneous strains and isolates of P. stutzeri (sensu lato) at the genomovar level.

Despite the observation that every species of Pseudomonas analysed presented a unique restriction pattern, more strains of each species will need to be analysed (studies in progress) before arriving at general conclusions about the utility of ITS1 restrictions for identification of strains at the species level.

\section{ACKNOWLEDGEMENTS}

The authors gratefully acknowledge A. Krüger and C. Strömpl for technical assistance in nucleic acid sequencing. C.G. thanks R. A. Rosselló-Mora for an introduction to non-radioactive DNA-DNA hybridization techniques, and J. Gil (Hospital Son Dureta) for the gift of clinical isolates. We also thank K. N. Timmis for advice and support. This work was supported, in part, by grants from the European Community (BIO2-CT94-3098), from the German Ministry of Education, Science and Research (BEO-0319433C), and from the Ministerio de Educación y Ciencia of Spain (CICYT AMB94-0760 and BIO97-0639). Fellowships from the Ministerio de Educación y Ciencia (Spain) to C.G. and A. B. are gratefully acknowledged.

\section{REFERENCES}

Abraham, W.-R., Strömpl, C., Meyer, H. \& 8 other authors (1999). Phylogeny and polyphasic taxonomy of Caulobacter species. Proposal of Maricaulis gen. nov. with Maricaulis maris (Poindexter) comb. nov. as the type species, and emended description of the genera Brevundimonas and Caulobacter. Int J Syst Bacteriol 49, 1053-1073.

Ash, C., Farrow, J. A. E., Wallbanks, S. \& Collins, M. D. (1991). Phylogenetic heterogeneity of the genus Bacillus revealed by comparative analysis of small-subunit-ribosomal RNA sequences. Lett Appl Microbiol 13, 202-206.

Barry, T., Colleran, G., Glennon, M., Dunican, L. K. \& Gannon, F. (1991). The $16 \mathrm{~S} / 23 \mathrm{~S}$ ribosomal spacer region as a target for DNA probes to identify eubacteria. PCR Methods Appl 1, 51-56 (erratum 1, 149).

Bennasar, A., Rosselló-Mora, R., Lalucat, J. \& Moore, E. R. B. (1996). 16S rRNA gene sequence analysis relative to genomovars of Pseudomonas stutzeri and proposal of Pseudomonas balearica sp. nov. Int J Syst Bacteriol 46, 250-255.

Bennasar, A., Guasp, C. \& Lalucat, J. (1998a). Molecular methods for the detection and identification of Pseudomonas stutzeri in pure culture and environmental samples. Microb Ecol 35, 22-33.

Bennasar, A., Guasp, C., Tesar, M. \& Lalucat, J. (1998b). Genetic relationships among Pseudomonas stutzeri strains based on molecular typing methods. J Appl Microbiol 85, 643-656.

Berg, K. L., Squires, C. \& Squires, C. L. (1989). Ribosomal RNA operon anti-termination. Function of leader and spacer region box B-box A sequences and their conservation in diverse microorganisms. J Mol Biol 209, 345-348.

Brosius, J., Palmer, M. L., Kennedy, P. J. \& Noller, H. F. (1978). Complete nucleotide sequence of a $16 \mathrm{~S}$ ribosomal RNA gene from Escherichia coli. Proc Natl Acad Sci USA 75, 4801-4805.

Brosius, J., Dull, T. J. \& Noller, H. F. (1980). Complete nucleotide sequence of a $23 \mathrm{~S}$ ribosomal RNA gene from Escherichia coli. Proc Natl Acad Sci USA 77, 201-204. 
Carlson, C. A., Pierson, L. S., Rosen, J. J. \& Ingraham, J. L. (1983). Pseudomonas stutzeri and related species undergo natural transformation. J Bacteriol 153, 93-99.

Felsenstein, J. (1989). PHYLIP - phylogeny inference package (version 3.2). Cladistics 5, 164-166.

Fox, G. E., Wisotzkey, J. D. \& Jurtshuk, P., Jr (1992). How close is close: 16S rRNA sequence identity may not be sufficient to guarantee species identity. Int J Syst Bacteriol 42, 166-170.

Fuller, W. \& Hodgson, A. (1967). Conformation of the anticodon loop in the tRNA. Nature 215, 817-821.

García-Martínez, J., Martínez-Murcia, A., Anton, A. I. \& Rodríguez-Valera, F. (1996). Comparison of the small 16S to 23S intergenic spacer region (ISR) of the rRNA operons of some Escherichia coli strains of the ECOR collection and E. coli K-12. J Bacteriol 178, 6374-6377.

Ginard, M., Lalucat, J., Tümmler, B. \& Römling, U. (1997). Genome organization of Pseudomonas stutzeri and resulting taxonomic and evolutionary considerations. Int $J$ Syst Bacteriol 47, $132-143$.

Guasp, C. M. (1999). Métodos moleculares de estudio de las poblaciones de Pseudomonas stutzeri. Doctoral Thesis, Universitat Illes Balears, Palma de Mallorca, Spain.

Gürtler, V. \& Stanisich, V. A. (1996). New approaches to typing and identification of bacteria using the $16 \mathrm{~S}-23 \mathrm{~S}$ rDNA spacer region. Microbiology 142, 3-16.

Gutell, R. R., Larsen, N. \& Woese, C. R. (1994). Lessons from an evolving rRNA: $16 \mathrm{~S}$ and $23 \mathrm{~S}$ rRNA structures from a comparative perspective. Microbiol Rev 58, 10-26.

Hauben, L., Vauterin, L., Swings, J. \& Moore, E. R. B. (1997). Comparison of $16 \mathrm{~S}$ ribosomal DNA sequences of all Xanthomonas species. Int J Syst Bacteriol 47, 328-335.

Hauben, L., Moore, E. R. B., Vauterin, L., Steenackers, M., Mergaert, J., Verdonck, L. \& Swings, J. (1998). Phylogenetic position of phytopathogens within the Enterobacteriaceae. Syst Appl Microbiol 21, 384-397.

Holmes, B. (1986). Identification and distribution of Pseudomonas stutzeri in clinical material. J Appl Bacteriol 60, 401-411.

Jensen, M. A., Webster, J. A. \& Strauss, N. (1993). Rapid identification of bacteria on the basis of polymerase chain reaction-amplified ribosomal DNA spacer polymorphisms. Appl Environ Microbiol 59, 945-952.

Johnson, J. L. (1973). Use of nucleic acid homologies in the taxonomy of anaerobic bacteria. Int $J$ Syst Bacteriol 23, 308-315

Johnson, J. L. (1984). Nucleic acids in bacterial classification. In Bergey's Manual of Systematic Bacteriology, vol. 1, pp. 8-11. Edited by N. R. Krieg \& J. G. Holt. Baltimore: Williams \& Wilkins.

Johnson, J. L. \& Palleroni, N. J. (1989). Deoxyribonucleic acid similarities among Pseudomonas species. Int J Syst Bacteriol 39, 230-235.

Jukes, T. H. \& Cantor, C. R. (1969). Evolution of protein molecules. In Mammalian Protein Metabolism, pp. 21-132. Edited by H. N. Munro. New York: Academic Press.

Kerkhof, L. (1997). A ribosomal RNA operon from Pseudomonas stutzeri ZoBell. Gene 192, 241-243.

Lane, D. J., Pace, B., Olsen, G. J., Stahl, D. A., Sogin, M. L. \& Pace, N. R. (1985). Rapid determination of $16 \mathrm{~S}$ ribosomal RNA sequences for phylogenetic analyses. Proc Natl Acad Sci USA 82, 6955-6959.

Leblond-Bourget, N., Philippe, H., Mangin, I. \& Decaris, B. (1996).
$16 \mathrm{~S}$ rRNA and $16 \mathrm{~S}$ to $23 \mathrm{~S}$ internal transcribed spacer sequence analyses reveal inter- and intraspecific Bifidobacterium phylogeny. Int J Syst Bacteriol 46, 102-111.

Lorenz, M. G. \& Wackernagel, W. (1994). Bacterial gene transfer by natural genetic transformation in the environment. Microbiol Rev 58, 563-602.

Manceau, C. \& Horvais, A. (1997). Assessment of genetic diversity among strains of Pseudomonas syringae by PCR-restriction fragment length polymorphism analysis of rRNA operons with special emphasis on $P$. syringae pv. tomato. Appl Environ Microbiol 63, 498-505.

Marmur, J. (1961). A procedure for the isolation of DNA from microorganisms. J Mol Biol 3, 208-218.

Martinez-Murcia, A. J., Benlloch, S. \& Collins, M. D. (1992). Phylogenetic interrelationships of members of the general Aeromonas and Plesiomonas as determined by $16 \mathrm{~S}$ ribosomal DNA sequencing: lack of congruence with results of DNADNA hybridizations. Int $J$ Syst Bacteriol 42, 412-421.

Mendoza, M., Meugnier, H., Bes, M., Etienne, J. \& Freney, J. (1998). Identification of Staphylococcus species by $16 \mathrm{~S}-23 \mathrm{~S}$ rDNA intergenic spacer PCR analysis. Int J Syst Bacteriol 48, 1049-1055.

Moore, E. R. B., Mau, M., Arnscheidt, A., Böttger, E., Hutson, R. A., Collins, M. D., Van de Peer, Y., De Wachter, R. \& Timmis, K. N. (1996). The determination and comparison of the $16 \mathrm{~S}$ rRNA gene sequences of species of the genus Pseudomonas (sensu stricto) and estimation of the natural intrageneric relationships. Syst Appl Microbiol 19, 478-492.

Moore, E., Arnscheidt, A., Krüger, A., Strömple, C. \& Mau, M. (1999). Simplified protocols for the preparation of genomic DNA from bacterial cultures. In Molecular Microbial Ecology Manual, 1.6.1, pp. 1-15. Edited by A. D. L. Akkermans, J. D. van Elsas \& F. J. de Bruijn. Dordrecht, The Netherlands: Kluwer Academic Press.

Obradors, N. \& Aguilar, J. (1991). Efficient biodegradation of high-molecular-weight polyethylene glycols by pure cultures of Pseudomonas stutzeri. Appl Environ Microbiol 57, 2383-2388.

Palleroni, N. J. (1984). Genus I Pseudomonas. In Bergey's Manual of Systematic Bacteriology, vol. 1, pp. 141-199. Edited by N. R. Krieg \& J. G. Holt. Baltimore: Williams \& Wilkins.

Palleroni, N. J., Doudoroff, M., Stanier, R. Y., Solanes, R. E. \& Mandel, M. (1970). Taxonomy of the aerobic pseudomonads: the properties of the Pseudomonas stutzeri group. J Gen Microbiol 60, 215-231.

Pérez-Luz, S., Rodríguez-Valera, F., Lan, R. \& Reeves, P. R. (1998). Variation of the ribosomal operon $16 \mathrm{~S}-23 \mathrm{~S}$ gene spacer region in representatives of Salmonella enterica subspecies. J Bacteriol 180, 2144-2151.

Rambaut, A. (1996). Se-Al: sequence alignment editor. Version 1.0 alpha 1. Department of Zoology, University of Oxford, South Parks Road, Oxford OX1 4JD, UK.

Riffard, S., Lo Presti, F., Normand, P., Forey, F., Reyrolle, M., Etienne, J. \& Vandenesh, F. (1998). Species identification of Legionella via intergenic 16S-23S ribosomal spacer PCR analysis. Int J Syst Bacteriol 48, 723-730.

Rosselló, R., García-Valdés, E., Lalucat, J. \& Ursing, J. (1991). Genotypic and phenotypic diversity of Pseudomonas stutzeri. Syst Appl Microbiol 14, 150-157.

Rosselló-Mora, R. A., Lalucat, J., Dott, W. \& Kämpfer, P. (1994). Biochemical and chemotaxonomic characterization of Pseudomonas stutzeri genomovars. J Appl Bacteriol 76, 226-233.

Rosselló-Mora, R. A., Lalucat, J., Timmis, K. N. \& Moore, E. R. B. 
(1996). Strain JM300 represents a new genomovar within Pseudomonas stutzeri. Syst Appl Microbiol 19, 596-599.

Shine, J. \& Dalgarno, L. (1974). The 3'-terminal sequence of Escherichia coli $16 \mathrm{~S}$ ribosomal RNA: complementarity to nonsense triplets and ribosome binding sites. Proc Natl Acad Sci USA 71, 1342-1346.

Sikorski, J., Graupner, S., Lorenz, M. G. \& Wackernagel, W. (1998). Natural genetic transformation of Pseudomonas stutzeri in a non-sterile soil. Microbiology 144, 569-576.

Sprinzl, M., Horn, C., Brown, M., loudovitch, A. \& Steinberg, S. (1998). Compilation of tRNA sequences and sequences of tRNA genes. Nucleic Acids Res 26, 148-153.

Srivastava, A. K. \& Schlessinger, D. (1990). Mechanism and regulation of bacterial ribosomal RNA processing. Annu Rev Microbiol 44, 105-129.

Stanier, R. Y., Palleroni, N. J. \& Doudoroff, M. (1966). The aerobic pseudomonads: a taxonomic study. J Gen Microbiol 43, 159-271.

Stewart, G. J. \& Sinigalliano, C. D. (1991). Exchange of chromosomal markers by natural transformation between the soil isolate, Pseudomonas stutzeri JM300, and the marine isolate Pseudomonas stutzeri strain ZoBell. Antonie Leeuwenhoek 59, 19-25.

Thompson, J. D., Higgins, D. G. \& Gibson, T. G. (1994). CLUSTAL W: improving the sensitivity of progressive multiple sequence alignment through sequence weighting, position-specific gap penalties and weight matrix choice. Nucleic Acids Res 22, 4673-4680.

Tyrrell, G. J., Bethune, R. N., Willey, B. \& Low, D. E. (1997). Species identification of enterococci via intergenic ribosomal PCR. J Clin Microbiol 35, 1054-1060.

Vaneechoutte, M., Boerlin, P., Tichy, H.-V., Bannerman, E., Jäger, B. \& Bille, J. (1998). Comparison of PCR-based DNA fingerprinting techniques for the identification of Listeria species and their use for atypical Listeria isolates. Int J Syst Bacteriol 48 , 127-139.

Wayne, L. G., Brenner, D. J., Colwell, R. R. \& 9 other authors (1987). International Committee on Systematic Bacteriology. Report of the ad hoc committee on reconciliation of approaches to bacterial systematics. Int J Syst Bacteriol 37, 463-464.

Yoon, J.-H., Lee, S.-T. \& Park, Y.-H. (1998). Genetic analyses of the genus Nocardioides and related taxa based on 16S-23S rDNA internally transcribed spacer sequences. Int J Syst Bacteriol 48, 641-650.

Ziemke, F., Höfle, M. G., Lalucat, J. \& Rossello-Mora, R. (1998). Reclassification of Shewanella putrefaciens Owen's genomic group II as Shewanella baltica sp. nov. Int J Syst Bacteriol 48, 179-186.

Zumft, W. G. (1992). The denitrifying prokaryotes. In The Prokaryotes, pp. 554-582. Edited by A. Balows, H. G. Trüper, M. Dworkin, W. Harder \& K. H. Schleifer. Berlin: Springer. 